\title{
Krystyna Ratajska (13 III 1938 - 14 X 2017)
}

Dr hab. prof. UŁ Krystyna Ratajska, z domu Waga, urodziła się w 1938 roku w Mnichach, w woj. wielkopolskim, w powiecie kaliskim. Pochodziła z rodziny nauczycielskiej. Mama, której po latach Krystyna poświęciła wspomnieniową książkę ${ }^{1}$, była nauczycielką z prawdziwego powołania, ofiarnie spełniającą misję edukacyjną i wychowawczą w szkole podstawowej w Mnichach i w Saczynie, dokąd państwo Wagowie przeprowadzili się jeszcze przed wojną. Wyniesione przez Krystynę z domu poczucie etosu zawodowego nigdy jej nie opuściło.

Ukończyła Liceum im. Anny Jagiellonki w Kaliszu, a następnie zamieszkała u swej cioci, również nauczycielki, w Zgierzu. W roku 1955 podjęła studia na łódzkiej polonistyce, by cztery lata później obronić pracę magisterską powstałą pod kierunkiem prof. Stefana Kawyna. Uważała się odtąd, aż do końca swej pracy naukowej, za uczennicę tego wybitnego badacza tradycji romantyzmu. Po studiach objęła stanowisko nauczyciela języka polskiego - najpierw w Szkole Podstawowej nr 3 (1960-1962), potem kolejno: w XXVI LO (wówczas im. M. Fornalskiej; 1963-1965), XXI LO im. B. Prusa (1965-1971) i XIII LO im. M. Piotrowiczowej (1971-1973). W latach siedemdziesiątych zaczęła również współpracować z Okręgowym Ośrodkiem Metodycznym w Łodzi, zaś w 1973 roku dołączyła do grona badaczy z Pracowni Metodyki Nauczania Języka Polskiego Uniwersytetu Łódzkiego. Współpraca z nauczycielami zawsze była bardzo bliska jej sercu, podobnie jak sprawy dydaktyki polonistycznej. Publikowała na ten temat wiele prac, uczestniczyła w licznych konferencjach i panelach, szukała nowych rozwiązań metodycznych, prowadziła cieszące się uznaniem warsztaty dla pedagogów i uczniów. Do ostatnich lat chętnie

$1 \quad$ K. Ratajska, Wspomnienia o naszej matce, Kalisz 2016. 
przyjmowała propozycje pracy $\mathrm{w}$ ramach zajęć popularyzujących literaturę, które organizowało Wojewódzkie Centrum Doskonalenia Nauczycieli w Łodzi. Była także zaangażowana w działanie Komitetu Okręgowego Olimpiady Literatury i Języka Polskiego. Zawsze podkreślano jej sumienność, oddanie, entuzjazm dla przedmiotu i życzliwość, zwłaszcza wobec młodego słuchacza.

$Z$ radością, a przede wszystkim z głębokim przekonaniem o celowości, udzielała się w Towarzystwie Literackim im. Adama Mickiewicza. Członkiem Oddziału Łódzkiego była od lat osiemdziesiątych XX wieku. Na początku XXI stulecia została przewodniczącą Oddziału i funkcję tę nieprzerwanie pełniła do roku 2016. W latach 2008-2012 była członkiem Zarządu Głównego Towarzystwa. Jako prezes Oddziału zabiegała o kontakty ze szkołami, przygotowywała cykliczne spotkania dla maturzystów w ramach Akademii Literatury, z których młodzież chętnie korzystała, oraz uczniowskie sesje popularnonaukowe (np. w Jubileuszowym Roku Juliusza Słowackiego).

Na uniwersytecie, w Zakładzie Metodyki, przepracowała blisko dwadzieścia lat. Podczas zajęć dydaktycznych chętnie inicjowała dyskusje o perspektywach szkolnej polonistyki, ale przede wszystkim pomagała swoim studentom w nauczycielskich „debiutach", nie szczędząc czasu na konsultowanie ich pomysłów. Dzięki jej uwagom niejeden początkowo niedopracowany lub niepełny konspekt lekcyjny stawał się interesującą i wartościową propozycją metodyczną. Potrafiła niemal z każdej osoby wykrzesać nauczycielski talent.

W roku 1982 obroniła rozprawę doktorską pt. Modele filomatyzmu i filaretyzmu w drugiej połowie XIX i na poczatku XX w. (na gruncie historii idei). Promotorem dysertacji była prof. Krystyna Poklewska. Na tej podstawie ukazała się z czasem wysoko ceniona w środowisku polonistycznym książka Dziedzice filomatyzmu (Wrocław 1987). W 1999 roku uzyskała habilitację w rezultacie pracy nad książką Neomesjanistyczni spadkobiercy Mickiewicza (Łódź 1998 [wyd. 1], Łódź 2010 [wyd. 2]), której recenzentkami były Maria Podraza-Kwiatkowska, Krystyna Poklewska i Alina Witkowska. W 2000 roku została pracownikiem Katedry Romantyzmu, Dwudziestolecia Międzywojennego i Literatury Współczesnej, a po przekształceniu jednostki należała do zespołu Katedry Literatury i Tradycji Romantyzmu. W 2008 roku przeszła na emeryturę.

Termin "tradycja” w nazwie zespołu został wprowadzony właśnie z myślą o Krystynie Ratajskiej. Zajmowała się przecież z wielkim oddaniem tropieniem „życia pośmiertnego" polskich romantyków, odnajdywaniem śladów romantycznego dziedzictwa w późniejszych okresach historii naszej kultury. Ciekawiły ją mechanizmy odradzania się myśli romantycznej „w jej różnych kształtach i wewnętrznym zdialogizowaniu"2. Krystyna Ratajska z pasją sięgała do zapomnianych tekstów, broszur, listów, biografii, dokumentów osobistych po to, by oficjalny przekaz historycznoliteracki wzmocnić i ożywić świadectwami codziennej, potocznej recepcji literatury. Śledziła rozmaite dysonanse $\mathrm{w}$ postawach, deklaracjach, poglądach twórców

2 Taż, Neomesjanistyczni spadkobiercy Mickiewicza, Łódź 2010, s. 7. 
romantycznych i poromantycznych, opisując uważnie, jak idea łączy się z praktyką życia. Wybierała do badań postacie nieraz drugiego planu, ale w większości zaskakujące, pełne zapału, czasem wręcz ekscentrycznego zaangażowania. Pociągały ją przykłady indywidualnego doskonalenia się, niekiedy heroicznego budowania swojej tożsamości. Potwierdzają to wnikliwe analizy Monsalwatu Artura Górskiego, pism Stanisława Szczepanowskiego, Kazimierza Odrzywolskiego, Wincentego Lutosławskiego, Bolesława Czerwieńskiego, młodzieńczych fascynacji Stanisława Pigonia, poezji Jana Lechonia.

Z czasem ważne okazały się dla niej również łódzkie ścieżki poezji, między innymi twórczość i osoba Juliana Tuwima - zarówno dojrzałego literata, jak i w jego dziecięcym wcieleniu ${ }^{3}$. Jeden z uniwersyteckich kolegów, Tomasz Cieślak, wspominał, że czuł się dumny, kiedy zdarzało się jej zadzwonić, żeby skonsultować coś dotyczącego Tuwima. „Przecież wiedziała o nim wszystko!"4 - mówił. Krystyna Ratajska poświęciła poecie liczne wędrówki po regionie, dociekliwie wynajdywała bliskie mu miejsca w Łodzi i okolicach, penetrowała zagadki biograficzne. Cieszyły ją drobne nawet odkrycia, poznani świadkowie przeszłości, zdjęcia, archiwalne dokumenty, wszystko, co mogło uzupełnić wizerunek autora Rzeczy czarnoleskiej. Jej artykuły i książki, zwłaszcza Kraj młodości szczęśliwy. Śladami Juliana Tuwima po Łodzi i Inowłodzu (Łódź 2002), dotąd budzą zainteresowanie czytelników, $\mathrm{i}$ to nie tylko polonistów. Poemat Kwiaty polskie - można śmiało rzec - znała niemal na pamięć! Owocem jednego z jej „śledztw literackich” była wydana w 2007 roku książka O mariażu bukieciarstwa z poezją. Do źródeł "Kwiatów polskich" Juliana Tuwima. I właśnie Kwiaty polskie stały się tematem jej ostatniego publicznego wystąpienia (które zamieszczamy w całości w bieżącym numerze naszego czasopisma) w Domu Literatury w Łodzi 13 września 2017 roku.

Dodajmy przy tej okazji, że była niebywale skromną osobą, która swoje osiągnięcia stale bagatelizowała i umniejszała, kwitując je często autoironicznymi słowami o „pisaninach", „drobiazgach", „książeczkach”.

Trzeba zaznaczyć, iż ponad owymi wysiłkami nauczycielskimi i zasługami naukowymi, których znakomitą merytoryczną wartość widać dobitnie po latach, była po prostu szalenie dobrym i życzliwym człowiekiem. Wychodziła naprzeciw każdego, z kim się spotykała, szukając w nim i w jego wypowiedziach najpierw tego, co według niej było wartościowe, słuszne, odkrywcze. Umacniała w wyborach, doradzała, upewniała w chwilach zwątpień. Pomagała i wspierała. Niemal nigdy nie krytykowała, a swoje wątpliwości wyrażała co najwyżej bystrym spojrzeniem i krótkim pytaniem: „Myślisz?”. W gronie kolegów i przyjaciół wprowadzała szlachetny duch koncyliacji i ożywionej dyskusji. Do tego obdarzona była zmysłem humoru

Taż, Julek. Podróże do krain wyobraźni Juliana Tuwima, Łódź 2013. To książka nie tylko o latach dzieciństwa Tuwima, lecz także pisana z myślą o dziecięcym odbiorcy.

4 Wspólnie redagowali tom Julian Tuwim. Biografia, twórczość, recepcja, Łódź 2007. 
i talentem gawędziarskim, który wnosił w zebrania katedralne niepowtarzalną, pogodną atmosferę. Znała teksty bodaj wszystkich pieśni patriotycznych i religijnych. Śpiewanie, któremu niejednokrotnie przewodziła podczas towarzyskich spotkań, sprawiało jej wielką radość. A przecież nie można zapomnieć, że życie jej nie oszczędzało. Kłopoty zdrowotne i rodzinne, których doświadczyła, mogłyby przytłoczyć niejedną osobę słabszego charakteru.

Śmiała się, że pochodzi z rodziny długowiecznej. W jej przypadku los okazał się mniej łaskawy, ale wszyscy mogliśmy Krystynie Ratajskiej pozazdrościć młodzieńczej witalności i twórczej energii. Zaskakiwał nas nieustanny zapał, prawdziwy pęd do pracy, ciągła potrzeba znajdowania sobie kolejnych wyzwań i wytrwałej ich realizacji, wbrew przeciwnościom. Była w niej ciekawość świata, która sprawiała, że wciąż zwiedzała nowe miejsca, fotografowała je, układała kolejne opowieści.

Do przyjaciół zawsze przychodziła z jakimś darem - z podróży przywoziła drobne prezenty, na zdjęciach utrwalała cudowne, przez nikogo innego niezauważane kształty, inspirowała powybieranymi z lamusa bon motami...

Tuż przed śmiercią Krystyna Ratajska pracowała nad tomem poświęconym łódzkim kawiarniom ${ }^{5}$. Przy tej okazji zgromadziła wiele fragmentów wierszy, wspomnień, opowiadań, mających utworzyć antologię towarzyszącą książce. Niestety, nie udało się tego pomysłu zrealizować. Wspominała także o nowym projekcie książkowo-fotograficznym, który roboczo nazwała "Szczęty”. W ten sposób określała wypatrzone przez siebie, a nośne znaczeniowo detale otaczającego świata, pozostałości czegoś, co skazane zostało na przemijanie, na powolne zapadanie w niebyt. Wielka była wrażliwość badaczki na naturę, na świat zwierząt i roślin, koegzystujący z ludzkim, a przecież - z czym trudno było jej się pogodzić - zaniedbywany i pogardzany przez człowieka. Kochała drzewa, ptaki, psy, przydrożne kapliczki, krzyże, pnie i kamienie, na których, przysiadłszy, rozmyślała. Poruszała ją „rzeczywistość utkana z okruchów pamięci, które wracały w myślach, zmuszały do zadumy, domagały się utrwalenia"6.

Naszą pamięć o Niej pewnie też Krystyna uznałaby za „szczątek”, mariaż zatrzymanych nagle gestów, spojrzeń, kolorów, dźwięków, obrazów, poczucia chwilowego wspólnego wędrowania...

„Droga kończy się niespodzianie, jakby nie wiedziała, po co istnieje. Żeby zrozumieć jej sens i szlak, którym wiedzie, trzeba rozejrzeć się uważnie i cofnąć w czasie. Wierna pamięć zaludni wówczas pustą przestrzeń i wypełni ją życiem, które odeszło"7.

Maria Berkan-Jabłońska Jerzy Wiśniewski

K. Ratajska, U Roszka, Fraszka, Honoratka. O niezwykłych łódzkich kawiarniach, Łódź 2018. Taż, To tu. Opowieści o drzewach i ptakach, Łódź 2017, s. 3.

Tamże, s. 6. 